\title{
THE STRUGGLE FOR RECOGNITION: PART-ABORIGINES IN BASS STRAIT IN THE NINETEENTH CENTURY
}

\author{
Lyndall Ryan
}

Resistance to an outside force, group or influence is a normal technique in the direction of human affairs. C.D. Rowley has characterized Aboriginal resistance to European invasion as 'normal reactions by members of any minority with a comparable history'.1 When Europeans invaded Australia the Aborigines were at first tentative in their response, but later they made definite overtures of friendship, based on mutual reciprocity, particularly to itinerant European invaders who were not intending to occupy Aboriginal land. When this was abused, the Aborigines resisted, usually by attacking the European camps. Where European invaders settled permanently, some Aborigines demanded payment for occupation. Where payment was not forthcoming Aborigines used guerilla methods to remove the invader.

When the Aborigines were dispossessed and placed in institutions they employed the resistance techniques of a defeated people to preserve their dignity and identity. They relied upon non-cooperation, silence, lying and ingratitude as well as acts of small scale defiance and affronts to middle class mores in order to outrage their captors. Kevin Gilbert has since pointed out that their treatment in defeat and captivity can be compared with the treatment of people in concentration camps. ${ }^{2}$

The dispossession of the Aboriginal people in south eastern Australia was foliowed not by the disappearance of Aboriginal groups but by the development of separate part-Aboriginal communities, for the spirit of survival and adaptation in Aboriginal society is as strong as in any other. These communities have fought for recognition despite attempts to legislate them out of existence. They have either been isolated from 'white' society because they have been considered too Aboriginal, or they have been denied Aboriginal legal status because they have been considered too European. Above all they have been considered incapable of self-determination.

This article explores the emergence and development of one partAboriginal community in south eastern Australia in the nineteenth century, the Cape Barren Islanders. It focuses upon their relations with the 'authorities' and 'outsiders' who made periodic attempts to change their identity and economy. The Islanders' resistance to these efforts is examined and their techniques for survival investigated.

The emergence of the part-Aboriginal community in Bass Strait in

1 1970:1-2.

$21973: 7$. 


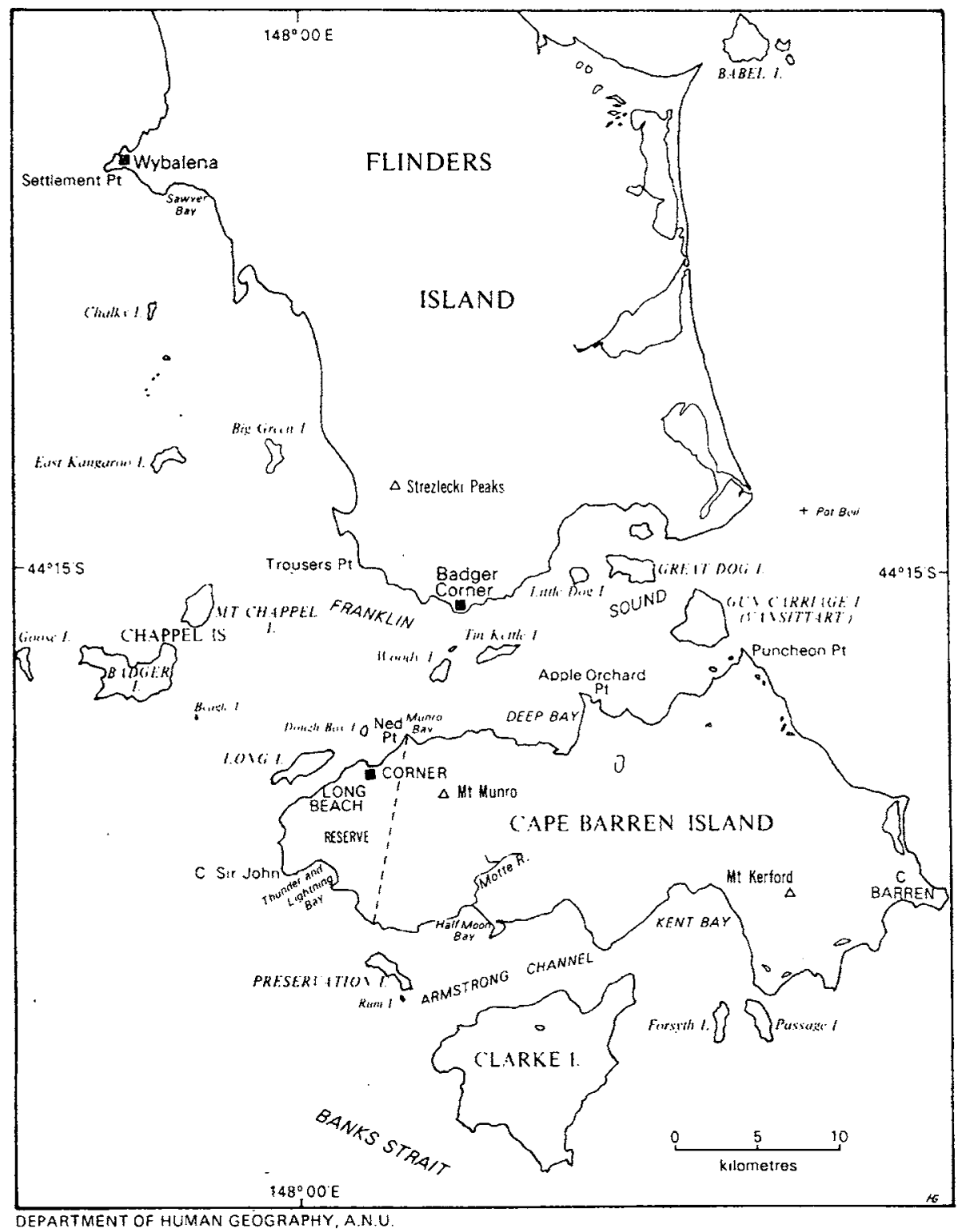

The Bass Strait Islands.

28. 
the nineteenth century was the result of interaction between Tasmanian Aborigines visiting the coastline of northern Tasmania in search of seasonal food resources and Europeans visiting Bass Strait in search of seal. Physical isolation allowed the community to develop a distinctive culture and lifestyle in much the same way that traditional Aboriginal society in Tasmania developed a separate but similar culture from Aboriginal society on mainland Australia after Bass Strait was flooded ten thousand years ago. Sealing from 1798 to 1820 initiated the community and mutton-birding from 1820 sustained it.

In pre-European times the Aborigines in Tasmania consisted of nine tribes each containing from five to twelve bands. With an average of nine bands, the population of each tribe comprised between 350 and four hundred people. The smallest tribe had about 250 and the largest seven hundred, so that the total population was probably about four thousand. ${ }^{3}$ Like most hunter-gatherer societies, the Aboriginal Tasmanians had an extensive system of reciprocal visiting rights for seasonal food sources, so that each tribe could take advantage of the 'maximum range of ecological zones'.4

Ecologically the tribes fell into three groups: the maritime group (the North West, the South West and the South East peoples) which had an extensive coast and limited hinterland; the eastern and northern group (the Oyster Bay, North East and North peoples) which had both an extensive coastline and hinterland; and the midland group (the Big River, the North Midlands and the Ben Lomond peoples) which had little or no coastline. By agreement, all three groups gained coastal and inland access to each other's territory. ${ }^{5}$ In pre-European times only the South East and South West peoples did not visit the north coast of Tasmania for the exploitation of seasonal food sources.European sealers first came to Bass Strait in 1798 in search of seal skins for the European market. The fur seal was then abundant along the coast of Tasmania and the southern shores of Australia. Bass Strait, with its rocky islands, temperate climate and plentiful supplies of fish, provided a perfect environment for them. ${ }^{6}$ The sealing season lasted from November to

3 Jones (1974:328) defines the tribe in Tasmania as:

That agglomeration of bands which lived in contiguous regions, spoke the same language or dialect, shared the same cultural traits, usually intermarried, had a similar pattern of seasonal movement, habitually met together for economic and other reasons, the pattern of whose peaceful relations were within the agglomeration and of whose enmities and military adventures were directed outside it. Such a tribe had a territory, consisting of the sum of the land owned by its constituent bands. Movements outside this territory, and of alien bands into it, were carefully sanctioned and had reciprocal economic advantages to the bands concerned. Trespass was usually a challenge to or punished by war. The borders of a territory ranged from a sharp, well-defined line associated with a prominent geographical feature to a broad transition zone usually found between two friendly tribes. Extraterritorial movement often took place along well-marked 'roads' that, in their configuration relative to the shape of the country and to the tribal boundaries, tended to give maximum access with minimum trespass.

tes 1974 .

5 Jones 1974.

6 Plomley 1966:1006. 
May with ships arriving from all parts of the world. At first the ships visited the islands taking as many seal as possible, but later they deposited groups of men on the islands for the season, returning to collect them the following May. The number of European men who came each year was never more than a few hundred and the very precariousness of the lifestyle frequently drove them to the coast of Van Diemen's Land for repairs and sustenance. ${ }^{7}$

They landed first at Cape Portland in about 1804 and later along the whole north coast of Tasmania from Cape Grim in the west to Georges Rocks in the east. Their visits coincided with the Aborigines' summer pilgrimage to the coast for mutton-bird, seal, birds and their eggs and shell fish.

The sealers' visits were not unwelcome to the North East people for they made no attempt to settle and were prepared to barter seal and kangaroo carcase, mutton-bird and later dogs for Aboriginal women. At first the women were bartered for the duration of the sealing season but after 1808 when the number of fur seal began to decline and the Sydney and foreign-based companies began to move to other areas, some sealers remained to operate independently in the Strait and Aboriginal women were taken to the Bass Strait islands to become their 'wives'. To maintain a supply of women for the sealers, the North East people began to raid neighbouring tribes more frequently. This led to increased inter-tribal rivalry. At the same time the North East people were convinced that the sealers could be incorporated into their own system of mutual obligation and exchange.

Every November the North East people gathered at strategic points along the north east coast such as Waterhouse Point, Cape Portland and Georges Rocks in anticipation of the sealers' arrival. After their appearance, usually in a whale boat containing four to six men, a dance was held, a conference would take place and an arrangement made for a number of women to accompany the sealers for the season. Some women came from the host band, others had been abducted from other bands. A 'sealing woman', Bullrer, from Cape Portland, told G.A. Robinson in 1830 that the North East people had taken women from the North Midlands tribe and sold them to the sealers for dogs, muttonbird and flour. 8 On other occasions sealers made arrangements to take

7 Hainsworth; Cumpston 1970, 1972; Micco.

8 Robinson, 20 October 1830 (Plomley 1966:254). George Augustus Robinson (1788-1866) was appointed by Lieutenant-Governor Arthur in March 1829 to 'effect an intercourse' with the Tasmanian Aborigines. After nine months at the Aboriginal ration station on Bruny Island, he set out in January 1830 to contact the Aborigines along the west coast of Tasmania. Between September 1830 and September 1831 he was in north-eastern and eastern Tasmania and on the islands of Bass Strait seeking information about the sealers. From October to December 1831 he was in central Tasmania searching for the Big River and October to December 1831 he February to November 1832 he was in north-western Tasmania; from December 1832 to October 1833 round Macquarie Harbour; and from December 1833 to August 1834 in the north-west again.

At first Robinson concentrated on establishing friendly relations with the Aborigines, 
women for short periods for specific tasks. When the sealer George Briggs visited the north east coast in January 1816, he was able to 'hire' six Aboriginal women to catch seal at Georges Rocks for two days.? Sometimes Aboriginal men accompanied sealing parties and Mannalargenna, the leader from Georges Bay who spent a great deal of his time in the north east, may have made more than one voyage with the sealers. 10

It is not known when the economic value of Aboriginal women in catching seal was first recognised by the sealers. But once this economic value had been understood, contact intensified and brought change both to the economy and society of the North East people. First the seasonal pattem of migration was changed. The North East people were now encouraged to remain on the coast for the whole summer rather than move inland for kangaroo as had been the traditional pattern. In winter they went in search of other bands and tribes along the coast to abduct their women. The second change was the increased power and influence of individual leaders. Mannalargenna, for example, who came from Georges Bay, spent many years with a band from St Patrick's Head. He led many raids for women on other bands, negotiated with sealers and quickly saw the value of European dogs to the Aboriginal economy and gift exchange system. Mannalargenna was able to exploit the sealers to the advantage of his own group. The final change was the increasing economic potential of the women. Their skills at first made them chattels in the barter system devised by the Aboriginal men and the sealers, but later proved a useful means with which to bargain for their independence. ${ }^{1}$

An example of the type of relations that developed between the North East people and the sealers was noted by James Kelly during his voyage around Tasmania in 1815 and 1816. With Kelly was the sealer George Briggs, who had at least two Aboriginal wives and several children on Cape Barren Island. In January 1816, Kelly and his crew landed at Ringarooma Point. There they fell in with a band of the

but during the second expedition he began persuading them to come into captivity, promising them a place where they could live unmolested by the settlers and be fed and clothed. Those agreeing to join him were sent to Bass Strait, first to Swan Island in November 1830 , then to Gun Carriage Island in March 1831 and to Flinders Island the following December. A permanent establishment began at Wybalenna on the western side of Flinders Island in January 1833. Over 230 Aborigines were taken to the Aboriginal Establishment; the fortyfour remaining were removed to Oyster Cove, twenty miles south of Hobart, in October 1847. The last of these, Truganini, died in May 1867 (Plomley 1966: Introduction; Anon.
1967).

Robinson was commandant at the Establishment from October 1835 to February 1839 , when he left to become Chief Protector of the Aborigines in Victoria. He held this post until 1849 and retumed to England in 1852. Robinson's manuscrip.t journals, now in the Mitchell Library, Sydney, provide extensive information about the Aborigines in Tasmania and Victoria. The Tasmanian journals for $1829-1834$ were published by N J.B. Plomley in 1966.

9 Bowden 1964:38-42.

10 Mollison 1972: n.p.

11 For an opposing view, see McMahon 1976: 44-49 
North East people, numbering two hundred and led by Mannalargenna, one of whose daughters Briggs had taken to Cape Barren Island.1 2 Through her Briggs had obligations to the rest of the band.

Mannalargenna had two daughters with the sealers: Teekoolterme, who was eventually taken to Kangaroo Island, and Wobberretee or Wapperty who at this stage was with Briggs although she had previously been abducted by the sealer John Thomas. She finally had a child to the Maori sealer, Myetye. ${ }^{3}$ Her descendants survive among the Cape Barren Island part-Aboriginal community.

Mannalargenna tried to elicit Briggs' assistance to fight a neighbouring band at Eddystone Point with whom the bushranger Michael Howe and his band had made an alliance. Having no wish to become entangled with Howe, Briggs promised Mannalargenna he would seek help from other sealers at Cape Barren Island. The leader agreed to this. As Briggs and his companions departed, the leader asked after his daughter. Briggs replied that she was very well. Mannalargenna said, 'I know, I see her fires every day from Cape Barren'. ${ }^{4}$

Briggs and his companions departed, but avoided Cape Barren Island and the adjacent north east coast and sailed instead for Georges Rocks on the east coast. In breaking his obligations to Mannalargenna, Briggs recognised that he faced future conflict. ${ }^{15}$

A few days later Briggs and Kelly fell in with the opposing band led by Tolobunganah near Georges Rocks. Michael Howe and his party had departed. Tolobunganah, who knew Briggs well, agreed to 'hire' him six women for two days to catch seal on Georges Rocks. In that time they killed fifty-four seal. Using other seal killed earlier, Kelly and Briggs traded 122 Carcases to Tolobunganah for 246 Kangaroo skins. 16

By 1820 the sealers were abducting Aboriginal women, partly because they were reluctant to barter valuable seal carcase, partly because of the general Aboriginal population decline and partly because they had begun to establish permanent villages on the Bass Strait islands where they needed women for economic and sexual purposes on a long term basis. Bullrer, an Aboriginal woman from Cape Portland, told Robinson in 1830 that she had been abducted by the sealer James Munro when she could only crawl. 17

By 1829 the society and economy of the North East people had been so disrupted by interaction with the sealing community and by increased hostility with neighbouring bands and tribes, that only thirty survivors remained. Although the sealers can be accused of destroying the North

12 Bowden 1964:86

13 Plomley 1966:1019-1020; Mollison 1972.

14 Bowden 1964:38.

15 Bowden 1964.

16 Bowden 1964:40-42.

17 Robinson. 11 October 1830 (Plomley 1966:246). 
East tribe through the barter of women and the creation of hostility toward the 'official' settler society, it can also be argued that the sealers saved the Aboriginal Tasmanians from extinction because their economic activity helped to create an alternative to the Aboriginal Establishment organised by Robinson on Flinders Island in the 1830s.

With the decline of sealing in Bass Strait after 1820, the community in Bass Strait began to place increasing emphasis upon mutton-birding. Before European contact the Aboriginal bands from northern Tasmania had gathered along the coastline every November to collect mutton-bird eggs. In February they had returned to eat the young birds. Muttonbirding had been more important to their traditional economy than sealing, as it was seasonally more reliable and exploited by all ages and both sexes.

One of the first sealers to recognise the economic potential of mutton-birding was James Munro, who had taken up residence at Preservation Island at the eastem end of Bass Strait in about 1819. By 1826 he had several huts, crops of wheat and potatoes and some livestock and employed fourteen Aboriginal women and thirteen European men in mutton-birding. Munro sold the feathers in Launceston for down, used the oil and fat for fuel and salted the carcase for storage against starvation in winter. ${ }^{18} \mathrm{He}$ had achieved a degre e of permanency in 1825 when he secured appointment as constable for the Straits area. He became the acknowledged voice for the community.

The Aboriginal women on Preservation Island had adapted their traditional technology to increase the catch. Their digging sticks, originally used to force the birds from their burrows, had been extended into spits, so that several birds could be carried at once by stringing them by their beaks. As the industry became more sophisticated over the next sixty years, both Aboriginal and European skills were used to maximise production. By 1830 'birding' had given the community a new economic security.

By 1830 there were seventy-four Aboriginal women living with sealers in Bass Strait. Twenty-eight came from the North East people, twenty-one from the North West and the remainder from the Ben Lomond, South East, Oyster Bay and North tribes. ${ }^{19}$

In the same year Robinson was authorised to remove Aboriginal women from those sealers who had more than one wife. Robinson regarded all Europeans in the Straits as fugitives from the law and all Aboriginal women associated with them as slaves. 20 He was convinced that if he could remove the women, the sealers would leave the Straits. With this in mind, in March 1831 he fixed upon one of their centres of

18 Plomley 1966:1014.

19 Ryan 1975:378.

20 Robinson, 9 December 1830 (Plomley 1966:294-295). 
residence, Gun Carriage Island, as the temporary headquarters of the Aboriginal Establishment. At that stage there were at least six sealers on the Island with nine Aboriginal women and their part-Aboriginal children. They lived in a 'village' of huts, gardens and livestock. Although most of the women had lived on the island since childhood, only four of the sealers had been there before 1820.21

The mode of exchange of women between the sealers, and the treatment they received, was a source of constant irritation and outrage for Robinson. He lost no time in removing most of the Aboriginal women and evicting the sealers, who went to Preservation Island. James Munro, however, took the sealers' case to Lieutenant-Governor Arthur in Hobart and extracted the promise that those sealers who had only one Aboriginal woman could have them returned. In June, Robinson had to return six women to the sealers. 22 But by then Gun Carriage Island had proved unsuitable for an Aboriginal Establishment and, at the end of 1831, it was removed to Flinders Island.

At least seventeen Aboriginal women were removed from the sealers and sent to the Establishment between 1830 and 1837.23 Robinson had hoped the 'sealing women' would assist in teaching the more recently captured Aborigines from the west coast some of the skills of European civilisation. Their better health, familiarity with European customs and readiness to dispense with some of the more 'distasteful' traditional ceremonial led him to believe that they could form the vanguard of the peasant society he had planned for Flinders Island. But the sealing women were critical of his Aboriginal Establishment and resisted both his authority and that of the Aboriginal men.

In August 1837 Robinson organised marriages for four sealing women because they had refused to cohabit with the Aboriginal men. ${ }^{24}$ Within a week, however, the women had left their husbands for the bush, warning that they would not return until they could live with whom they chose. When Robinson refused to supply them with rations they robbed the camp at night.2 5 By the end of 1837 the sealing women had emerged as a significant dissident group. By 1838 Robinson recognised that his program of 'civilisation by tuition' had only a limited chance of success. ${ }^{26}$

The sealing community in Bass Strait consisted in 1837 of forty people scattered on Gun Carriage, Preservation, Clarke, Woody and Swan islands. Several South Australian women had been brought to the islands before. 1831, and the son of a settler from Oyster Bay, George

\footnotetext{
21 Robinson, 17 March 1831 (P'omley 1966:324); Plomley 1966:452 note 132, 1010-1020.

22 Robinson, 19 March and 6 June 1831 (Plomley 1966:325, 360).

23 Ryan 1975:374-889.

24 Robinson, Flinders Island Journal, 10 August 1837, Robinson Papers v.11.

25 Journal, 17 August 1837, Robinson Papers v. 11.

26 Robinson to Colonial Secretary, 4 July 1838, Robinson Papers v. 24.
}

34. 
Meredith Jr., had raided the southern coast of Australia for women in 1835 , to replace those who joined Robinson. Thus a number of Victorian Aboriginal women had joined the community. Until his departure for Port Phillip in 1839, Robinson used his authority to refuse the sealers the right to depasture sheep, destroy game or exploit mutton-bird. Yet he purchased mutton-bird from them when stores failed to arrive from Hobart. 27

After Robinson's departure, succeeding commandants at the Aboriginal Establishment took a more pragmatic view of the sealing community and, until the Establishment's removal to Oyster Cove in 1847, a degree of interaction took place. Some Aborigines from the Establishment accompanied the sealers on sealing and mutton-bird expeditions. One sealer, John Smith, was a coxswain for the Establishment and another, Thomas Tucker, occasionally taught the children. At least two Aboriginal men tried to abscond from the Establishment with the sealers and at least one Aboriginal woman resident bore a child to a sealer. Two Aboriginal women from the community joined the Establishment when their sealer 'husbands' died, but one, Wapperty, left her child with the community. ${ }^{28}$

In March 1847 the then commandant, Henry Jeanneret, invited three sealers from Gun Carriage Island - Thomas Beedon, Richard Maynard and John Dobson - to attend a meeting in the chapel at the Establishment where he publicly charged the catechist with neglect of the Aboriginal children. ${ }^{29}$ By using the sealers as witnesses, Jeanneret accorded the community a respectability and status the colonial government had for years sought to deny. At that time another member of the Straits community, John Thomas, was sheltering at the Establishment after his farm at Clarke Island had been appropriated by a European from the Australian mainland. ${ }^{30}$

Interaction ceased in October of 1847 when the Aboriginal Establishment was removed to Oyster Cove, twenty miles from Hobart. The ostensible reasons for this removal were expense and humanity but a more significant influence was the fear that too much interaction with the Straits community would 'contaminate' the remaining 'fullbloods'. Miscegenation might increase the numbers at the Establishment, which would mean an even greater burden upon government. It was now recognised that the Aborigines had some claim upon the public purse in compensation for dispossession, although this claim was a strictly

27 Plomley 1966:1009; An Act to require sealers and others to depart the Straits, 6 Will. IV. no. 18, 1836; Robinson, Journal, 30 August 1836, Robinson Papers v. 24; Colonial Secretary to Robinson, 25 February 1839, Robinson Papers v. 50.

28 Plomley 1966:1020; Plomley $1971: 28$; see also Jeanneret to Colonial Secretary, 21 February, 31 March and 20 May 1843, Tasmanian State Archives, Colonial Secretary's Office (TSA CSO 8/157/1166).

29 Jeanneret 1854:34-35.

30 Jeanneret $1854: 35$. 
limited one. Miscegenation was also condemned on the ground that it would produce an inferior person who would comprise all that was 'weak' in both black and white. ${ }^{31}$

The removal of the 'fullblood' Aboriginal Tasmanians to Oyster Cove sealed their fate because they had fewer means to resist their institutionalised environment. Had they remained at Flinders Island these Aborigines could have increased their number by interaction with the Straits community, which had adapted to the realities of the Bass Strait environment, and provided a positive alternative to the artificial society at the Aboriginal Establishment.

In 1847 the Straits community consisted of thirteen families totalling about fifty people. On Gun Carriage Island there was Thomas Beedon who lived with a woman from Cape Portland, Emerenna (Bet Smith), also known as Woreterneemmerunnertatteyanne, and their four children; Thomas Tucker who lived with an Indian woman, Maria Bengally; and David Kelly with his part-Aboriginal son. ${ }^{32}$ Also on Gun Carriage Island were John Riddle and his children..$^{3}$ On Woody Island lived James Everett and Wottecowidyer (Wot, Wotty or Harriet), also from Cape Portland, and their four children. Richard Maynard also lived there with an Aboriginal Tasmanian, Margaret or Pollerwottelterkunne, from Piper River, by whom he had two children, and the Aboriginal Australian woman, Elizabeth, by whom he had four children. An earlier inhabitant, Andrew Armstrong, and his Aboriginal Australian wife, Jane Foster, and two of their children had recently left the island for the west coast of Tasmania to engage in sealing, but later returned to Clarke Island. ${ }^{34}$ On Long Island lived Edward Mansell and Julia (Black Judy) from St Patrick's Head and their child. On Tin Kettle Island lived John Smith and his three children by Sarah (Mother Brown) or Pleenperrenner from Cape Portland. ${ }^{35}$ On Cape Barren Island lived John Thomas and Nimerana or Teekoolterme, a daughter of Mannalargenna, and at least three children, as well as Robert Rew and his partAboriginal wife, Frances Anderson. On Preservation Island was the Aboriginal Australian, Margery, who had lived with James Munro until his death in 1845, and two of her children. On Hunter Island lived William Proctor and the part-Aboriginal Tasmanian, Mary Ann Brown, and two of their children. ${ }^{36}$ There were other families on Kangaroo Island but those associated with the Furneaux Group remained in sufficient contact to form the 'Islander' community as they became known. Three other European men entered this community in the

31 Strzelecki 1845:344-346.

32 See genealogical table no. 4, Everett family, in enclosure Bladon to Premier of Tasmania, 30 September 1911, Bladon Papers; Report of the Surveyor-General on the Islands in Bass Strait 1849, (TSA LSD 24/66).

33 Plomley 1966:1015.

34 Mollison 1977, notes on Armstrong family.

35 Sarah had died in July 1846.

36 Mollison 1977, notes on Proctor family; see also Tindale 1953:10-15. 
succeeding twenty years - William Richard Brown, John Summers and George Burgess. After that the Islanders married within their own community, forming the basis of the present-day grouping. ${ }^{37}$

The community in the 1840 s was seen by the outside world in sharply differing ways. Some observers found the elders 'hale, rubicon fellows, hearty and joyous', and the children 'sharp and intelligent'. Others found them 'barbarous', 'literally half-savage and half-civilised; half black and half white'. ${ }^{8}$ Having survived eviction and harassment, they now began to seek recognition as a separate community.

In February 1848 Thomas Beedon, a resident of Gun Carriage Island, applied to the Van Diemen's Land government for the lease of Badger Island, but was refused on the ground that the island could be needed for the construction of a lighthouse. The government was not anxious to legitimise a community which had long evaded regulation. ${ }^{39}$ But the Bass Strait islands were beginning to attract other settlers, so in the following year the government decided that the Surveyor-General should make an official visit, to make recommendations on future occupation.

He found the Islander community scattered throughout the Furneaux Group. They ran pigs and goats and grew wheat and potatoes to supplement catches of kangaroo, seal and mutton-bird, they visited each other's establishments, sometimes for months at a time, to exploit seasonal food resources and they pursued a lifestyle based on elements from both traditional Aboriginal and nineteenth century European society. The Surveyor-General found the Islanders

... kind and gentle; and upon the whole I consider them a primitive and amiable people, and believe that the greatest harmony prevails amongst them. The men are excellent boatmen and possess a capital description of whaleboat... every encouragement should be given to a class of men most invaluable as Pilots, and whose kindness was evinced by their treatment of the shipwrecked survivors of the Governor Phillip. 40

He recommended that a nominal rent of one shilling a year be paid by the Islanders for occupation of their existing places, on the understanding that the Crown possessed the right of resumption at six months notice. The government, too recognised that 'the occupation of the Islands by acknowledged Tenants is better by far than having them occupied without leave or licence'.4 1

Two years later the community applied to Lieutenant-Governor Denison for the appointment of a missionary-catechist to educate their

37 Mollison 1977; Tindale.

38 J. Milligan to R.C. Gunn, 17 November 1844, Gunn Papers; J.B. 1845:188; see also Stokes 1846.

39 Report of the Surveyor-General ... 1849 (TSA LSD 24/66).

$40 \mathrm{Ibid}$

41 Colonial Secretary to Denison, 7 January 1850 (TSA CSO 24/93/3033). 
children. They suggested that by virtue of their Aboriginality the salary of such a person should be paid from the Land Fund which also maintained the Aboriginal Station at Oyster Cove. The Lieutenant-Governor refused their application on the ground that they 'could not fairly be termed Aborigines', despite the fact that at least seven 'full-blood' Aboriginal Tasmanians were in the community. In his view there was only one official Aboriginal community in Van Diemen's Land - the Aboriginal Station at Oyster Cove. But he suggested that Bishop Nixon might take an interest in the Islanders' welfare. 42

The geographical remoteness of the Islander community proved an attraction to the Anglican Church in Tasmania. In contrast to the inhabitants of the Aboriginal Station at Oyter Cove, the Islanders in their comparative isolation appeared sober and industrious, sheltered from the 'pernicious influences' of the 'lower orders' of white society. The newly established missionary society for the diocese of Tasmania wrote of the Islanders: 'The young men are prepossessing in their manners and address, and of athletic frame: the girls are modest in their demeanour, and can make themselves useful in domestic affairs'. The society considered that these people should have some claim on any projected missionary enterprise. ${ }^{43}$

In September 1854 Bishop Nixon paid his first visit to the Islanders, accompanying Surveyor-General Power. At Gun Carriage Island, still the centre of the community, he baptised some children and married Edward Mansell and the Aboriginal Tasmanian Judy Thomas, who had lived together for twenty-five years. Lucy Beedon, aged twenty-five, the part-Aboriginal daughter of Thomas Beedon and Emerenna, had become the teacher. She had received a good education in Launceston and was already involved in the business interests of the community.44 Like the surveyor-general in 1849 , the bishop was impressed with the Islanders' air of 'quiet domestic union' and apparent innocence of drunkenness and theft. The Islanders, however, took the opportunity to protest the harassment they received from Europeans illegally occupying nearby islands, who interfered with their mutton-birding. ${ }^{45}$

This visit persuaded the government to lease other islands to the community. Between 1855 and 1860 the Maynards and George Everett's family moved to Cape Barren Island, and the Beedons to Badger Island. By 1861 the Waste Lands Amendment Act made available for lease islands or parts of islands for periods up to fourteen years and in 1865 the community received permission to lease areas up to 550 acres. The rapidly increasing numbers of the community severely tested their

42 Tasmanian Church Chronicle, 6 March 1852.

43 Ibid.

44 Anon. (TSA M/M no. 79).

45 Nixon; Report of Surveyor-General Power, September/October

$1854 \ldots$. (TSA LSD 1/51/35).

38. 
established decision-making processes, which depended upon reciprocal arrangements. It was no longer possible for John Riddle to depasture his sheep on Thomas Beedon's lease on Gun Carriage Island in the dry season, in exchange for Beedon's 'birding' on Riddle's rookery. Some of the older members of the community, such as Margery Munro, were left destitute on Preservation Island. The long-established seasonal visiting patterns had survived, but with greater concentration upon family groups, and a general congregation at the end of the muttonbird season. Thus the Islanders had their 'private' and 'public' seasons of the year.

The outside world was almost completely excluded from their proceedings. They operated their leases according to their needs, often incurring the wrath of the Lands Department which found their noncooperation infuriating. One officer wrote in 1861:

I ... hardly think ... any of the Straits inhabitants can be relied upon as I have most conflicting accounts given me by them of different matters. In fact they seem reluctant to give any information - they are evidently a most indolent, shiftless race of beings. ${ }^{4} 6$

But they were concerned to educate their children. When Thomas Beedon died in 1862, his daughter Lucy found her business responsibilities precluded her from continuing to teach, so she invited Archdeacon Thomas Reibey and Reverend George Fereday to the islands to discuss the appointment of a teacher, after agreeing that the Islanders would raise a portion of the salary. Reibey photographed the Islanders and reported to the Tasmanian Parliament, but was unable to produce a teacher. ${ }^{47}$ Lucy Beedon later appointed two teachers from Melbourne. Concerned that the Islanders should not become alienated from the Anglican Church, Reibey launched an appeal to raise $£ 500$ for a missionary boat to make regular visits to the Islands. At the same time Fereday agreed to act as the Islanders' agent on the Tasmanian mainland. 48

But in 1866, following a misunderstanding over the renewal of licence fees, some Islanders lost the opportunity to renew their leases of the major mutton-bird islands. Taking advantage of this, a recently arrived outsider purchased four 40-acre blocks on Chappell Island, which contained the largest mutton-bird rookery in Bass Strait, as grazing land for his sheep.49 The Surveyor-General dismissed the Islanders' protests that sheep disturbed the rookeries even though they were removed during the mutton-bird season. 50

In desperation the Islanders pursued the only avenue available to them as a part-Aboriginal community - they petitioned Governor Du

46 John Thomas to the Surveyor-General, September 1861 (TSA LSD 1/51/52).

47 Reibey 1862.

48 Reibey 1863 .

49 Survey or-General to Colonial Secretary, 17 February 1868 (TSA LSD 1/51/32).

so George Everett to Surveyor-General, 30 November 1869 (TSA LSD 1/51/32); Lord.

39. 
Cane for exclusive rights to mutton-birding on Chappell Island and requested that an island be granted to them, to serve as the focal point of their life and identity. 51

In August 1871 the Governor held a meeting with the Islanders at Goose Island. Du Cane sympathised with their grievances and pressed their claims upon the government. 52 The government, reluctant to grant land in Bass Strait, offered the Islanders (under the Waste Lands Act of 1870) five to twenty-five acre blocks for homestead and agricultural land, on the western end of Cape Barren Island. It also gazetted Chappell and Big Dog Islands as mutton-bird rookeries under the Game Preservation Act. 53 The government had thus accepted the Islanders as a separate community and had protected the major rookeries from further incursion. But it had denied the Islanders ownership of land and exclusive rights to the rookeries by virtue of their Aboriginal descent.

Cape Barren Island, at the western end of Bass Strait and part of the Furneaux Group, is about twenty-three miles long and seventeen miles wide. It is separated from its larger neighbour, Flinders Island, by Franklin Sound. Named for its barren appearance by Tobias Furneaux in 1774, it has granite peaks and low-lying scrub. The land, though 'quite unfit for cultivation', can graze sheep and cattle. 54 With few trees to afford protection against the westerly gales, dependence is placed upon coves to provide shelter, particularly the area known as the 'Corner' on the western side of the island. Its immediate marine environment abounded at that time in crayfish and seal. The area between Thunder and Lightning Bay and Ned's Point had been inhabited at various times by the Islanders from about 1810. Apart from white families at Apple Orchard Point on the northern side and at Puncheon Head opposite Vansittart or Gun Carriage Island, it had attracted few 'outsiders', although there were 143 European settlers in the Furneaux group in 1872.55 .

By the end of 1872 seven Islander families consisting of thirty-two adults and fifty-two children had settled on Cape Barren Island. They extended geographically from the George Everett family at Thunder and Lightning Bay in the south, then John Smith and family at Long Beach, young John Maynard and Thomas and Jarnes Mansell at the 'Corner', Thomas Rew at Rooke's River and William Brown at Munro Bay. The approximately two-mile distance between each household was overcome by constant visiting, meetings and expeditions. With old John Maynard on Long Island, the Beedons at Badger Island and old Edward Mansell at Passage Island, the community had become closer

s1 Church News, April 1871.

52 Memo from DuCane to Ministers, 14 August 1871 (TSA CSD 7/45/833).

53 Hobart Town Gazette, 30 April 1872; Burbury.

54 Brownrigg 1872:79.

55 Murray-Smith 1973:184. 
physically than at any period since the $1820 \mathrm{~s} .{ }^{56}$ The appointment of a schoolmaster, Henry Collis, who taught at Badger Island in the winter and at Long Beach in the summer, had given the community a recognition and stability never previously experienced. 5 ?

The community had retained many traditions from its Aboriginal and European founders. Most families spent the summer on Cape Barren Island and, at the end of the mutton-bird season in May, travelled to Badger Island for the winter. In July many collected shells for stringing and in November there was a further congregation for 'egging'. It was still common for a number of families to visit each other until 'the neck of the flour bag became a little long'. 58 The celebratory gatherings at the end of the mutton-bird season were as important as the season itself, for the Islanders drew no distinction between work and leisure. Singing was as important as mutton-birding, curing kangaroo and seal skin as important as sharing the flour bag.

The women continued the traditions of their mothers, such as stringing shell necklaces. At certain times of the year a range of shells the Aboriginal Tasmanian women had traditionally used for stringing were washed ashore. The young women combed the beaches, selecting with great care the types of shell needed for the painstaking process of stringing. In the evenings they would string the shells into delicate, intricate patterns. One present-day resident recalls that as a child she had to string for several hours each evening, taking months to complete one necklace. For this woman, stringing is still an important aspect of her existence. 59

With the concentration of the community in one area, Canon Brownrigg of Launceston began regular missionary visits to conduct baptisms and marriages and to inspect the schools. From the start, Brownrigg wanted the leasehold land on Cape Barren Island converted to a reserve and for the next fourteen years, through his articles in the Launceston Examiner and Church News, he pursued his view that the Islanders needed 'guidance' in order to acquire 'civilised' habits. This was reinforced by the visit of Bishop Bromby in 1876. In his view the Islanders were a godless community, addicted to drunkenness and sloth. He had no doubt that their Aboriginal ancestry was responsible for this 'moral weakness' which was further manifested by the fact that they did not cultivate the land. He wanted a settled community which would relinquish the pursuit of mutton-bird, properly attend to the

56 Brownrigg 1872:6.

57 DuCane to Ministers (TSA CSD 7/45/833).

58 Launceston Examiner, 8 March 1885.

59 Sarah Mansell, personal communication, 30 July 1973. 
soil and receive tuition in the 'sober virtues' of respectable white society. 60

The Islanders wanted protection from harassment in the mutton-bird industry and from the threatened loss of land for debt. Some Islanders had not paid leasehold rent because they considered the land theirs by occupation or by virtue of their Aboriginal ancestry. ${ }^{61}$ So, for different reasons, the Islanders and the Anglican Church sought to have the leasehold area of Cape Barren Island legally associated with the Islanders.

In February 1881 the Administrator of the Colony of Tasmania withdrew from lease 3,500 acres of land on the western end of Cape Barren Island, from Thunder and Lightning Bay to Munro Bay, together with a further five hundred acres of Crown Land.62 The government intended the land for the exclusive use of the Islanders but did not wish to name them nor officially extend to them any rights or privileges by virtue of their Aboriginality. The Islanders had lost the right to lease land in favour of right of occupation but had no control over the land and no security of tenure. The proclamation represented a confused if well-intentioned attempt to protect them but it fell short of their needs.

At first the Islanders thought they had been granted land and set about planning a township. But when they learned that they had no security of tenure and that the government could revoke the proclamation at any time, some families departed for Flinders Island. Only Brownrigg's assurances that revocation was unlikely brought some back. By 1884 some families at the 'Corner' had built cottages, launched boats and erected fencing. Brownrigg was optimistic that the means had been established for the eventual transformation into agriculturalists. ${ }^{6}{ }^{3}$ He did not understand that the Islanders' relationship to the land rested on their Aboriginal heritage, their pursuit of mutton-birding and their descent from a sealing community. Agriculture had never been a significant part of their existence.

To the outside world the Islanders were now a separate community whose lifestyle placed them beyond government assistance. If the Islanders were to achieve continuing recognition, it would only take place through the 'protectionist-development' policies of the Anglican church.

In 1889 the Right Reverend H.H. Montgomery arrived in Hobart as the fourth bishop of Tasmania. He was deeply committed to help the 'unfortunate sable people of the earth' in their struggle to receive the

60 Launceston Examiner, 6 February 1876; Murray-Smith 1973:184-185; Rowley 1970:100.

61 Collis to Chairman of the Board of Education, 1 August 1881 (TSA CSD 13/6/168).

62 Hobart Town Gazette, 15 March 1881.

63 Launceston Examiner, 8 March 1884. 
christian faith and learn the rudiments of European civilisation. $64 \mathrm{He}$ attacked the 'problem of the half-castes' with the enthusiasm of someone who was able to lose himself entirely in the joys of the unfamiliar. He noted that, unlike their 'full-blood' counterparts at Flinders Island sixty years before, the Islanders were increasing in numbers. Since they already lived in an isolated environment and were seeking assistance for a new schoolteacher, he believed it possible to undertake a programme of instruction in the principles of christianity and agriculture. $6 \mathrm{~s}$

Montgomery persuaded the Minister for Education to appoint to the community a 'missionary schoolteacher' who would exemplify christian standards of behaviour, instruct the children and their parents in horticulture and agriculture and combine the functions of postmaster and governmental representative. The island would take on the air of a training institution with the habits of the Islanders under constant scrutiny.

The missionary schoolteacher appointed was Edward Stephens, then aged forty-seven. He arrived with his family at the 'Corner' in August 1890. He found a community of 110 perople, consisting of thirty adults and eighty children, who earned a livelihood from muttonbirding, piloting stores, sealing, whaling, fishing, itinerant labouring and snaring animals. For four months of the year, from February to May, the community was absent mutton-birding. In July some of the women were shelling at Thunder and Lightning Bay and in November many of the men visited the rookeries for mutton-bird eggs. Most families contained about ten people, housed in wooden cottages of two to four rooms surrounded by small gardens, with goats, pigs, poultry, some sheep and a few horses. 66 With no shop, church, school, police station or post office, the jetty was the focal point for the community. Having been without a schoolteacher for some time, the Islanders hailed Stephens' arrival with enthusiasm.

Stephens had known Aborigines since his childhood in South Australia. He had turned to missionary work because he wanted to control his desire for alcohol. During eight years on the island, Stephens operated a repressive system of law and order in conformity with the reserve system then developing in other parts of Australia. The Islanders were at first impressed by his concern for their welfare but as they became aware of his own failings and his determination to control their lives, they withdrew their friendship and retreated into non-cooperation. Finally they were forced to resist in more positive fashion to protect themselves.

Six months after Stephens' arrival, Montgomery paid his first visit.

64 Hart 1963:49.

65 Church News, December 1891:563.

66 Entry for 9 July 1899, Register of Services ... (TSA NS 373/11). 
He listened to the Islanders' requests for more favourable mutton-bird regulations and their pleas for landownership, baptised a number of their children, inspected the new school, decided to build a church and to consecrate a cemetery and departed a week later, promising to present their grievances to the Premier.6 7

Montgomery had quite different ideas for their advancement. Rather than pressing their claim for communal ownership of land, he recommended to the Premier that each Islander family be allocated a block of land near the school under the watchful eye of the schoolmaster and that if horticulture were not undertaken, then the lease should be withdrawn. Instead of pressing for the communal lease of mutton-bird rookeries he recommended the introduction of a family licence system where the Islanders would compete rather than cooperate during the mutton-bird season. 68 For Montgomery was determined that the spirit of private ownership and individual achievement should replace the Aboriginal communalism which he considered had been responsible for their moral decline. He was now confident that:

kept from drink, encouraged to become farmers by judicious grants, prevented from intermarrying too much, these islands would be a happy region, famed for its salubrity and out of reach of the greater temptations. 69

On his second visit in 1892 Montgomery was deceived by Stephens into believing that the Islanders had made 'steady progress' towards 'civilisation'. In an address written by Stephens and signed by the Islanders, he was told they observed the Sabbath, regarded the schoolteacher and his family with reverence and respect and manifested gratitude for Montgomery's interest in their welfare. 70 But Stephens was again wrestling with his craving for alcohol and a few weeks earlier had written in his diary: "This has been the most horrible year I can ever remember. I have not touched a drop of intoxicating liquor the whole year'.71

Stephens' difficulties were exacerbated in June 1892 with the appointment of a constable to supervise the new mutton-bird regulations. Stephens insisted that this second white official should attend Sunday services as well as refraining from drink and the use of bad language. The constable, who displayed his own eccentricities of character, eventually manifested his wrath by firing shots at the schoolhouse where Stephens was conducting Sunday service. 72

By 1894 , tensions at the Corner had become so intolerable that some

67 Church News, August 1891:444-445.

68 Church News, December $1891: 563$.

69 Church News, August 1891:444-445.

70 The Inhabitants of Cape Barren Island to Montgomery, 5 February 1892, Montgomery Papers.

71 E.W. Stephens, Diary, November 1891 (ML MSS 1248/2).

72 Diary, 11 September 1892. 


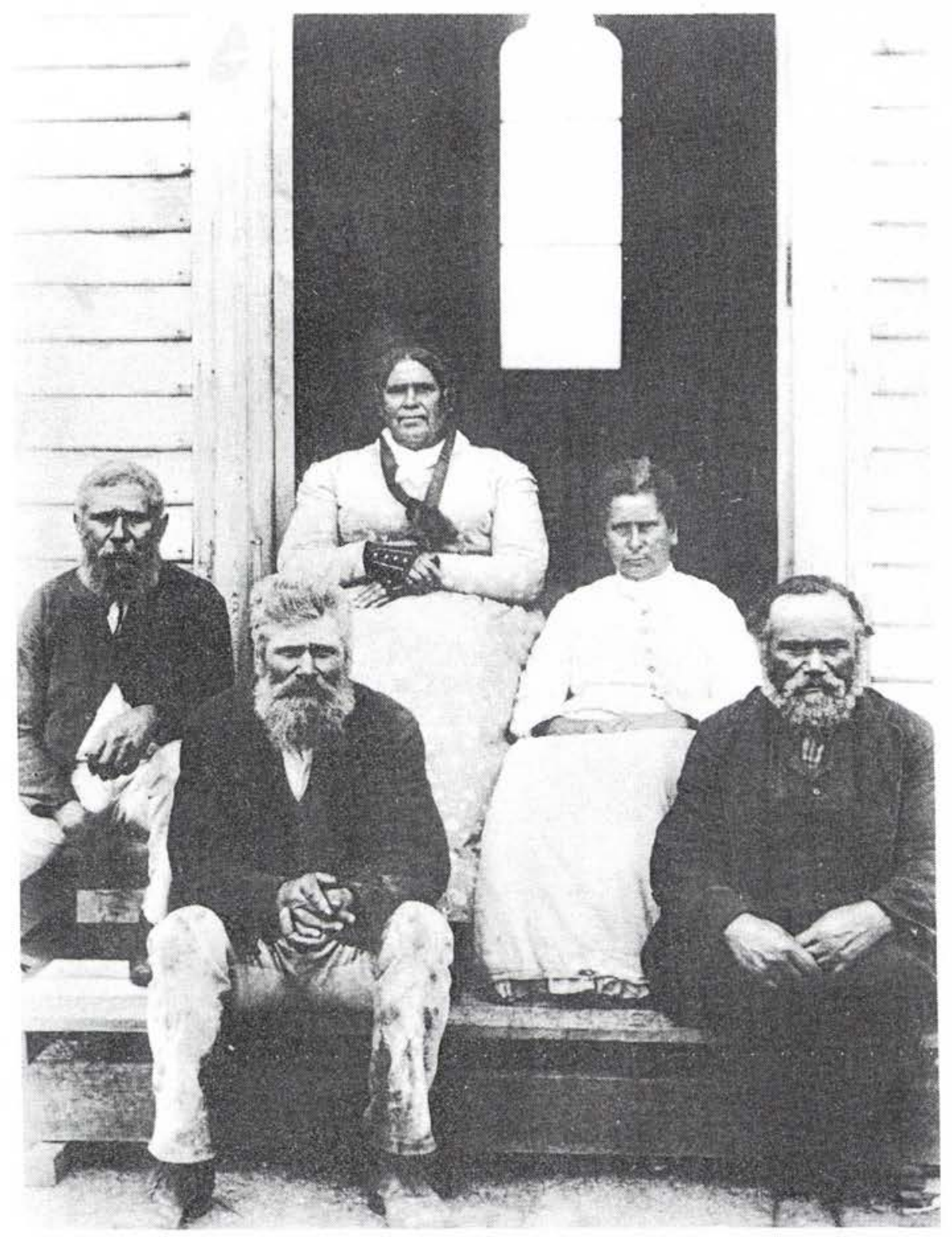

Five 'half-castes', Cape Barren Island Reserve, 1891. Courtesy of Tasmanian State Archives. 

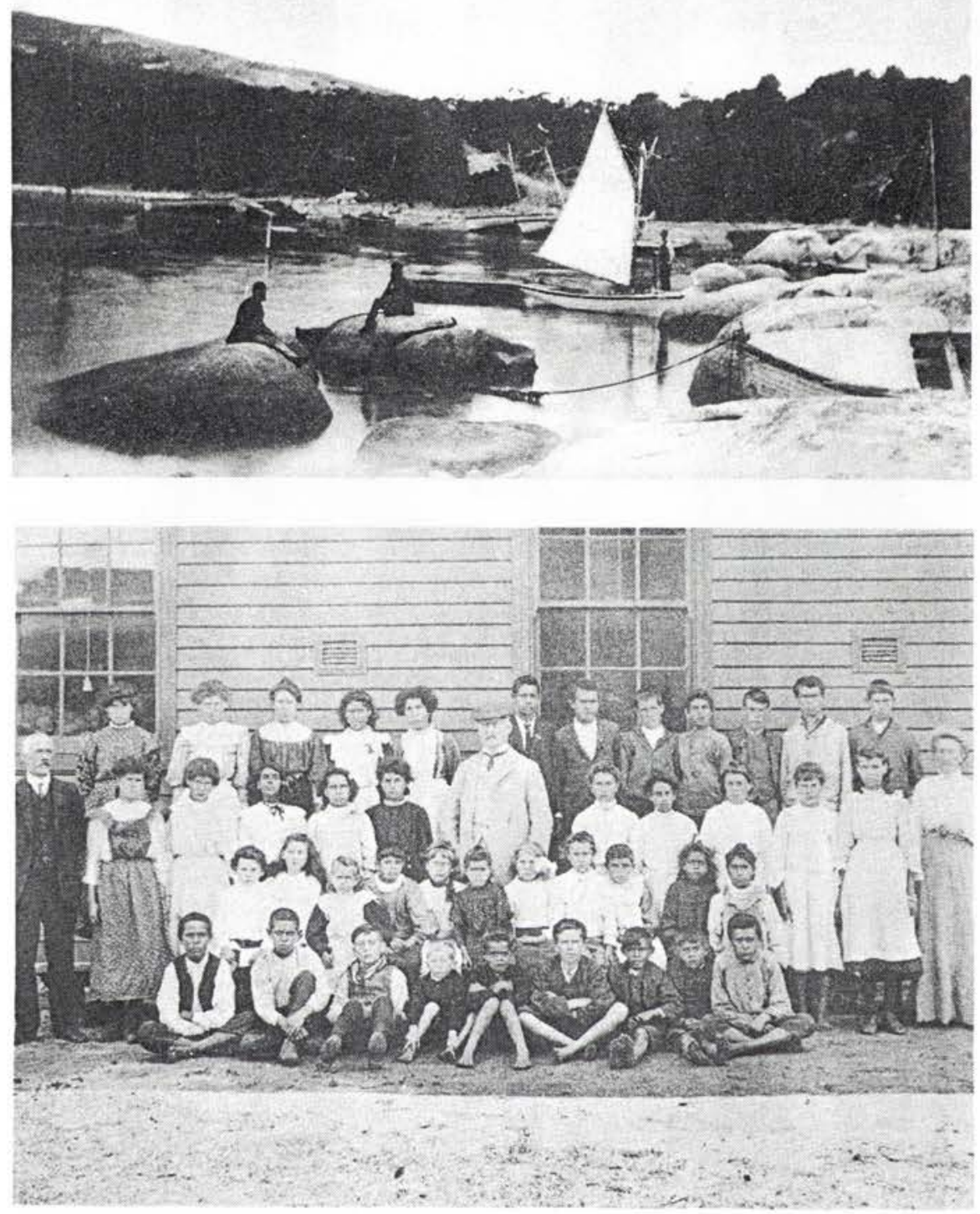

Top: Boat Harbour, The Corner, Cape Barren Island, 1893.

Bottom: Cape Barren schoolchildren with the Governor of Tasmania, Sir Harry Barron, January 1911.

Courtesy of Tasmanian State Archives.

46. 
Islanders departed for Flinders Island while others kept their children from the school. 73 The climax came in October 1895 when the ketch G.V.H. was wrecked off the west coast of the island with the loss of three lives. Stephens accused the Islanders of displaying false lights to cause the ship to founder, intending to loot its cargo. 74

In retaliation the Islanders accused Stephens of adultery and attempted murder, of appearing before the children in a beastly state of intoxication', and locking their children out of the school. Driven to the limits of endurance, Stephens fired shots at two Islanders entering the boat harbour and, it was reported, threatened to 'shoot all the halfcastes or any other caste be damned if he wouldn't'.7 5

Stephens wds summoned to Hobart to explain himself. There Montgomery learnt for the first time how Stephens had become the butt of the Islanders' mockery, a common pattern of Aboriginal defensive behaviour. For a moment Montgomery faltered, and then determined that Stephens' work must continue. Reprimanded for drunkenness, Stephens was sent back to the island. ${ }^{76}$

But the Islanders had had enough. If he was not replaced, they informed the Director of Education, all the children would be removed from the school.77 In September 1896 they accused Stephens of threatening them with a pistol. He accused them of incest and adultery. In Hobart Montgomery explained his disillusionment to the Minister for Education:

All that Stephens says about the Half-castes is just what I believe to be true. They are not improving except in some families. When they have tired of one man and they know he knows too much about them, they will try to get rid of him. 78

By the time the Director had admonished the Islanders for their ingratitude, Stephens had suffered a nervous collapse and surrendered his position to his son, Charles. During his convalescence, Stephens wrote of his difficulties with the Islanders:

As liars I do think the men are peerless. I will give one instance at my own expense. It went the round of the islands, and was believed to be a fact, that Bishop Montgomery, on one of his visits, found me sitting on the roof of the water closet; and I had only my nightshirt on, and was singing the national anthem! He asked me what I was doing and I told him "I was showing my loyalty to the Queen". He said, "Oh, come down and come inside and we will make a

73 Church News, August 1894:123-125; Report of J. Masters, Education Department, 7 August 1893 (TSA ED 110/732); Annual Examination, Cape Barren School, 19 November 1894 (TSA ED 110/733).

74 E.W. Stephens to Montgomery, November 1895, Montgomery Papers.

75 Anon. to Minister for Education, 12 February 1896 (TSA ED 3713/1077).

76 Montgomery to Rule, 9 March and 7 April 1896 (TSA ED 3713/1077); see also Rowley $1970: 96$.

77 T.E. Mansell to Rule, 12 May 1896 (TSA ED 3713/1077)

78 Montgomery to Minister for Education, 4 October 1896 (TSA ED 110/335). 
night of it". And we did so. They said they knew I was a drunkard but the Bishop was a "bloody sight worse!"

He concluded that if such stories were commonly believed, then the life of a civil servant was 'an ever-increasing torment from which there was no escape, but by resignation or suicide'. 79

Stephens had no understanding of the Islanders' need to pursue their lifestyle on their terms. He saw their defensive behaviour as another example of their perversity and lack of intelligence, also manifested by the failure of any one of them to announce his conversion to "civilised society' or even to wish to become a catechist. 80

The Islanders considered Stephens' retirement their victory. In 1897 they formed an Islander Association which initiated petitions to government concerning mutton-birding and land tenure and attempted to establish a newspaper and a health benefit organisation.81 But neither Montgomery nor Charles Stephens could tolerate any display of Islander independence and saw the existence of the Association as a threat to their authority. In 1898 Montgomery took the Chief Inspector of Education to the island and in the following year, the Minister for Justice. A meeting called with the latter attracted only four Islanders. 82 The presence of such authority figures had driven many into the scrub, for they had been threatened with the loss of their leasehold land on the ground that it had not been cultivated. 83

To further undermine the Islander Association, Montgomery recommended to the Commissioner of Police in August 1899 that a committee of inquiry should investigate the condition of the 'reserve' and the mutton-bird industry and that a police magistrate should visit the island to hear some cases that had been outstanding for years. He wrote:

I believe the terror of the proceedings in the eyes of these natives would be such that the evils now existing would be checked. At present I believe every known sin short of murder is rife here, and no evidence can be obtained.... Nothing would do more than the stern hand of the law at this time. 84

Montgomery now believed it had been a mistake to concentrate the " "half-castes" into a township which had brought its own special evils'. They had developed a 'settled hatred' for himself, the schoolmaster and the constable, and had expressed a wish not to become 'like white people'.8 5

By October 1899 Islander resistance to Charles Stephens reached its

79 E.W. Stephens, The Furneaux Islands, their early settlement and some characteristics of their inhabitants. Stephens Papers.

80 See Rowley 1970:96-99 for further discussion of missionary attitudes.

81 Charles E. Stephens to Montgomery, 28 November 1899, Montgomery Papers.

82 Entry for 12 August 1899, Register of Services ... (TSA NS 373/11).

83 Hart 1963:62-63.

84 Montgomery to Police Commissioner, 26 August 1899, Montgomery Papers.

85 Ibid. 
peak. "They will give the Government more trouble than the Boers are giving Great Britain', he wrote in despair. ${ }^{86}$ He decided to concentrate on Bible history in the school curriculum, in the hope that they would be terrorised into submission. He now believed that the second and third generation 'half-castes' were of weaker character than the first and needed more rigid instruction. But the Islanders could still make life very difficult:

They actually stand on the bank out of my sight, with a clock and check my time of going into school with theirs, then they lie in the sun until it is time for the children to go home, when they look at the clock to see if it is exactly to the minute. If a little before, they would get up a petition saying that the teacher was overtaxing the brains of the scholars. 87

In May 1900 the report of the Committee of Inquiry recommended an annual licencing fee for mutton-birding and proposed that the land originally withdrawn from lease in 1881 be thrown open to Islander selection with fourteen years to pay. Those Islanders not wishing to cultivate the land could lease a homestead block of five acres at the rental of one pound a year, the remainder of the land could then be leased to outsiders. 8 \& Fortunately only the mutton-bird licensing system was enacted. But with the land ownership issue unresolved, the Islanders found their occupation of the 'reserve' was as insecure as at any time since 1881.89 This insecurity was exacerbated in 1902 when Chappell Island was leased for grazing in the 'off season'. The Islanders were constantly aware of covetous settlers seeking to alienate their land.

Montgomery departed Tasmania after a final visit to the Islanders in August 1901, no more aware of the Islanders' needs as a separate community than upon his arrival twelve years before. His successor, Bishop Mercer, hardly bothered about their existence. In Hobart the view was taken that since Montgomery had failed to earn their gratitude, it was unlikely that anyone else would. In 1902 a debate in the Tasmanian Parliament on the future of the Island lapsed for want of a quorum.90

The attempt by church and state to bring 'civilization' to Aboriginal communities in eastern Australia between 1880 and 1900 was part of the campaign for egalitarian conformity which swept the Australian colonies at this time. The fortunes of these communities, of which the Cape Barren Islanders are an example, oscillated between regulation and indifference. If they did not conform to accepted 'standards of

86 Charles E. Stephens to Montgomery, 28 November 1899, Montgomery Papers.

$87 \mathrm{Ibid}$.

88 Charles E. Stephens to Montgomery, 29 May 1900, Montgomery Papers.

89 Launceston Examiner, 27 August 1902.

90 T. Reibey to E.W. Stephens, 3 October 1902, Stephens Papers. 
civilization' they became outcasts in their own country. There was no opportunity for self-determination.

\section{AUSTRALIAN NATIONAL UNIVERSITY}

\section{BIBLIOGRAPHY}

Anon. Notes on Cape Barren Islanders. Tasmania State Archives, Hobart (M/M no. 79).

'Robinson, George Augustus (1788-1866)', Australian Dictionary of Biography, $2,1967: 385-387$.

Bladon, J.B. Bladon Papers. Royal Society of Tasmania Archives, University of Tasmania.

Bowden, K.M. Captain James Kelly of Hobart Town. Melbourne, 1964.

J.B. [John Broadfoot]. 'An unexpected visit to Flinders Island in Bass Straits', Chambers' Edinburgh Journal, 20 September 1845: 187-189.

Brownrigg, M.B. The cruise of the Freak. Launceston, 1872.

Burbury, M.B. Report on the condition of the half castes at Cape Barren Island Reservation, 25 September 1929. Tasmanian State Archives, Hobart. (TSA CSD $22 / 336 / 104 / 37)$.

Cumpston, J.D. Kangaroo Island 1800-1836. Canberra, 1970. The Furneaux Group, Bass Strait: first visitors 1797-1810. Canberra, 1972.

Gilbert, Kevin. Because a white man'll never do it. Sydney 1973.

Gunn, R.C. Gunn Papers. Mitchell Library, Sydney. (ML A316).

Hainsworth, D.R. 'Iron men in wooden ships: the Sydney sealers 1800-1820', Labour History, (13), 1967:19-25.

Hart, P.R. The Church of England in Tasmania under Bishop Montgomery, 1889 . 1901. University of Tasmania, M.A. thesis, 1963.

Jeanneret, Henry. Vindication of a colonial magistrate. London, 1854.

Jones, Rhys. 'Tasmanian tribes', Appendix in Tindale, N.B. Aboriginal tribes of Australia... Berkeley, 1974: $317-354$.

Lord, J.E.C. 'Furneaux Islands: report upon the state of the islands... 31 August 1908', Parliament of Tasmania, Journals and Papers, 59 (57), 1908.

McMahon, Anne. 'Tasmanian Aboriginal women as slaves', Tasmanian Historical Research Association, Papers and Proceedings, 23 (2), 1976: 44-49.

Micco, H.M. tr. King Island and the sealing trade, 1802: a translation of chapters $X X I I$ and $X X I I I$ of the narrative by François PEron....Canberra, 1971.

Mollison, B.C. Genealogy of the Tasmanian Aborigines. Hobart, 1972. Tasmanian Aboriginal genealogies, with an appendix on Kangaroo Island, to October 1976. Hobart, 1977.

Montgomery, H.H. Montgomery Papers. Tasmanian State Archives, Hobart.

Murray-Smith, Stephen. 'Beyond the pale: the Islander community of Bass Strait in the 19th century', Tasmanian Historical Research Association, Papers and Proceedings, 20 (4), 1973:167-200.

Nixon, Francis R. The cruise of the Beacon ... . Hobart, 1854.

Plomley, N.J.B. ed. Friendly mission: the Tasmanian journals and papers of George Augustus Robinson, 1829-1834. Hobart, 1966.

Plomley, N.J.B. 'Friendly mission... a supplement', Tasmanian Historical Research Association, Papers and Proceedings, 18 (1), 1971:1-32.

Reibey, T. 'Letter from the Venerable Archdeacon Reibey, on the subject of the half-caste Islanders in the Straits', Legislative Council of Tasmania, Joumals and Papers, 7 (17), 1862.

'Half-caste Islanders in Bass Straits', Legislative Council of Tasmania, Journals and Papers, 9 (48), 1863.

Robinson, George Augustus. Robinson Papers, Mitchell Library, Sydney. Vols. 11, 
24,50. (ML A7032, A7059, A7075).

Rowley, C.D. The destruction of Aboriginal society. Canberra, 1970.

Ryan, Lyndall. The Aborigines in Tasmania 1800-1974 and their problems with the Europeans. Macquarie University, Ph.D. thesis, 1975.

Stephens, Edward W. 'The Aborigines of Australia, being personal recollections of those tribes which once inhabited the Adelaide Plains of South Australia', Royal Society of New South Wales, Journal, 23, 1890: 476-503.

'The Tasmanian half-castes of the Furneaux Islands', Manchester Geographical Society, Journal, 14 (10-12), 1898:355-360.

Stephens Papers, Royal Society of Tasmania Archives, University of Tasmania. Writing, notes and correspondence of E.W. Stephens, Mitchell Library, Sydney. (ML MSS 1248/2).

Stokes, John Lort. Discoveries in Australia.... London, 1846. 2 v.

Strzelecki, P.E. de. Physical description of New South Wales and Van Diemen's Land. London, 1845.

Tasmanian State Archives, Chief Secretary's Department. (TSA CSD 13/6/168; TSA CSD $7 / 45 / 833$; TSA CSD 22/336/104/37).

Colonial Secretary's Office. (TSA CSO 8/157/1166; TSA CSO 13/6/168; TSA CSO 24/93/3033).

Education Department. (TSA ED 110/335; TSA ED 110/732;TSA ED 110/733; TSA ED 3713/1077).

Lands and Survey Department. (TSA LSD 24/66; TSA LSD 1/51/32; TSA LSD $1 / 51 / 35$; TSA LSD $1 / 51 / 52$ ).

Register of Services held in the Church of the Epiphany, Cape Barren Island, 24 January $1898-2$ March 1924. (TSA NS 373/11).

Tindale, Norman B. 'Growth of a people: formation and development of a hybrid Aboriginal and white stock on the islands of Bass Strait, Tasmania, 1815-1949', Queen Victoria Museum, Launceston, Records, n.s. 2, 1953.64p. 